Doświadczenie mistyczne w religiach niechrześcijańskich.

Perspektywa filozoficzna

„Filozofia Chrześcijańska” 17 (2020), s. 167-178

JOANNA PICEWICZ

Akademia Ignatianum w Krakowie

Wydział Filozoficzny

\title{
Teologiczna interpretacja pojęcia arché u wczesnych filozofów greckich: w kręgu teologii milezyjskich filozofów przyrody
}

Filozofia europejska miała swój początek (VII-VI wiek przed Chrystusem) w filozofii przyrody ${ }^{2}$. Na jońskich wybrzeżach Azji Mniejszej grupa wybitnych filozofów przyrody: Tales z Miletu ${ }^{3}$, Anaksymander z Miletu ${ }^{4}$ oraz Anaksymenes z Miletu ${ }^{5}$, podjęła próbę zrozumienia świata pod kątem jego struktury i mechanizmu wszelkich przemian rzeczywistości, za pomocą wysiłku intelektualnego ${ }^{6}$. Niezmienne pytanie o początek, źródło i zasadę wszechrzeczy ${ }^{7}$,

${ }^{1}$ Zainteresowania naukowo-badawcze dotyczą filozofii Zdzisławy Piątek.

${ }^{2}$ A. Łukasik, Wprowadzenie, w: Filozofia przyrody wspótcześnie, red. M. Kuszyk-Bytniewska, A. Łukasik, Kraków 2010, s. 5-6.

3 Tales z Miletu (ok. 624-545 p.n.e.) - uznawany za pierwszego filozofa oraz badacza przyrody reprezentującego cywilizację zachodnią. Był także politykiem, matematykiem i astronomem przewidział zaćmienie Słońca 28 maja r. p. n. e. Związany ze szkołą milezyjską. Zob. G.S. Kirk, J.E. Raven, M. Schofield, Filozofia przedsokratejska, thum. J. Lang, Warszawa-Poznań 1999, s. $88-99$.

${ }^{4}$ Anaksymander z Miletu (ok. 610-546 p.n.e.) - wybitny uczeń oraz następca Talesa z Miletu, matematyk i astronom. Przedstawiciel szkoły milezyjskiej. Prawdopodobnie jest autorem pierwszego w historii ludzkości dzieła filozoficznego zatytułowanego O naturze. Tamże, s. 109-112.

${ }^{5}$ Anaksymenes z Miletu (ok. 585-525 p.n.e.) - uczeń oraz następca Anaksymandra z Miletu, związany ze szkołą milezyjską. Wykładnię swoich filozoficznych myśli zawarł w dziele zatytułowanym $O$ naturze. Tamże, s. 149-151.

${ }^{6}$ M. Subczak, Antyczna tradycja filozoficznych sposobów życia jako wzorzec dla współczesności, „Logos i Ethos”, nr 1 (44), 2017, s. 8.

${ }^{7}$ G.E.R. Lloyd, Nauka grecka od Talesa do Arystotelesa, thum. J. Lesiński, Warszawa 1998, s. 23-29; por. także R. Palacz, Klasycy filozofii, Warszawa 1987, s. 12-18. 
zaprowadziło greckich myślicieli do poszukiwań arche ${ }^{8}$, które jest praprzyczyną i prazasadą świata, w którym egzystowali. Poszukiwano prazasady, już nie pojedynczej dla jednostkowego wydarzenia, ale ogólnej, która wyjaśniałaby wszystko, co istniało i co powstawało ${ }^{9}$. Przedmiotem rozważań u pierwszych filozofów nie było powstanie świata w sensie jego początku w czasie, tylko interesował ich pierwotny składnik, z którego wyłonił się świat materialny. Świat ten składał się z różnych obrazów rzeczywistości: z jednej strony był zbudowany $z$ wielości zmiennych elementów, natomiast $\mathrm{z}$ drugiej, stałości i niezmienności, w ciągle tak samo następujących po sobie przemianach nocy i dni, pór roku czy harmonijnego dopasowania przeciwieństw. Greckie pojęcie arché zawierało $\mathrm{w}$ sobie właściwość nieskończoności, która jest zasadniczo religijna w swym charakterze. W greckim świecie-kosmosie ${ }^{10}$, owa nieskończoność mająca cechy boskie, była wpisana na stałe w tkankę rzeczywistości, w której dostrzegano niezwykłą harmonię i porządek w całej jej jedności. Grecki świat-kosmos jest odzwierciedleniem absolutnego ładu, odwiecznie zadanej wewnętrznej harmonii oraz dyscypliny istnień we wzajemnych relacjach. Jest jednolitą uporządkowaną strukturą $\mathrm{z}$ wielkim łańcuchem bytów, w której ma swoje miejsce wielość istnień. Doskonały kosmos jest jednością w nieustannej przemianie, wszelkie przeobrażenia podlegają jednemu, wiecznemu prawu, które jest wspólne dla materii ożywionej i nieożywionej. „Stałe są tylko relacje, a wszelkie przejawy życia podlegają ciągłej przemianie"11. $\mathrm{W}$ takim rozumieniu świata człowiek był jednym z elementów rzeczywistości. Jego natura stanowiła część składową natury Wszechświata, a jego rozum część powszechnego rozumu boskiego, zatem żyć zgodnie z naturą, znaczyło żyć zgodnie z ładem ustanowionym na świecie, z prawami natury, z odwiecznym Logosem ${ }^{12}$. Odejście od praw Logosu doprowadza do samozagłady, gdyż w ten sposób człowiek, stając ponad naturą, będzie działał jedynie na własną szkodę ${ }^{13}$. W rozumieniu greckim świat funkcjonował na podstawie zasady sprawiedliwości i umiaru, zatem ludzkie aktywności powinny

${ }^{8}$ Arché z gr. 'zasada', 'przyczyna', 'prasubstancja wszystkich bytów', 'podstawowy składnik rzeczywistości'. Dla uzupełnienia pragnę dodać, że pojęcie arché w filozofii W. Tatarkiewicza i E.I. Zielińskiego jest rozumiane jako 'zasada', natomiast u F. Coplestona jest rozumiane jako 'pierwotny element czy substrat' rzeczywistości. Zob. W. Tatarkiewicz, Historia filozofii, t. 1, Warszawa 1978, s. 27-28; G. Reale, Historia filozofii starożytnej, t. 1, thum. E.I. Zieliński, Lublin 2000, s. 76; F. Copleston, Historia filozofii, t. 1, thum. H. Bednarek, Lublin 2004, s. 26.

9 D. Dembińska, Moja krótka historia filozofii starożytnej, „Studia Redemptorystowskie”, nr 11, 2013, s. 26.

${ }^{10}$ Kosmeo z gr. oznacza - 'ład', 'porządek'.

${ }^{11}$ A. Hajduk, Trzy aspekty ekologii Seneki i św. Franciszka, w: Ekologia i spoleczeństwo: Polityka i etyka wobec zagadnień ekologicznych, red. A. Delorme, Wrocław 2001, s. 56.

${ }_{12}$ M. Aureliusz, Rozmyślania, II 17, thum. M. Reiter, Warszawa 1988, s. 12.

${ }^{13}$ A. Hajduk, Trzy aspekty..., s. 54. 
być ugruntowane na poczuciu obowiązku wobec całości, w której człowiek żyje ${ }^{14}$. Aktywność człowieka miała być odzwierciedleniem piękna rozumnego świata. W owej rzeczywistości było miejsce dla istot doczesnych, czyli śmiertelnych, ale także był to świat nieśmiertelnych bogów ${ }^{15}$. Warstwa boska nie podlegała ograniczeniom czasowo-przestrzennym, typowym dla śmiertelnych ludzi. Bogowie kosmosu charakteryzowali się cechami ponadludzkimi, takimi jak: wieczna młodość i nieprzemijające piękno, absolutna mądrość, niebywała siła oraz nieśmiertelność ${ }^{16}$.

Zadaniem niniejszej pracy będzie próba przedstawienia jednego zasadniczego problemu: określenia istotnych cech arché u milezyjskich filozofów przyrody przez wskazanie możliwych związków z teologią.

\section{Zagadnienie arché u milezyjskich filozofów przyrody}

\section{1) Tales z Miletu}

Tales z Miletu uznawany jest powszechnie za pierwszego filozofa cywilizacji europejskiej. Źródła naukowe nie podają, że myśliciel ten pozostawił po sobie spuściznę w postaci tekstów filozoficznych czy zapisków. Wszystko, co wiemy o Talesie, zawdzięczamy przekazom innych filozofów ${ }^{17}$. Mędrzec ten nie dysponował uporządkowaną wiedzą, która wyjaśniałaby przyczyny i prawidłowości zdarzeń. Szukając początków wszystkiego, co jest, istnieje, filozof postawił pytanie samej przyrodzie.

Według Talesa świat-kosmos został zbudowany z jednego tworzywa materialnego, z którego wywodzą się wszechrzeczy i na które w końcu się rozpadają. Owo tworzywo nie zmienia się, jego struktura jest niezmienna, jego istota jest zawsze taka sama. Jak podaje Diogenes Laertios, „Tales uczył, że początkiem wszechrzeczy jest woda" ${ }^{18}$. Zgodnie z myślą Talesa, woda to żywioł i zasada, z której wszystko, co istnieje, bierze początek i w której odnajduje swój kres ${ }^{19}$. Ma zdolność przybierania różnych form istnień: postać człowieka, kamienia, roślin czy powietrza. Przybierając różne formy, nie potrzebuje żadnej

${ }^{14}$ D. Dembińska, Moja krótka..., s. 24.

${ }_{15}$ M. Jastrzębski, Wczesna filozofia Grecka jako archaiczna droga do nieśmiertelności. Próba rekonstrukcji, Białystok 2014, s. 161.

16 Tamże, s. 160.

${ }^{17}$ Należy tutaj wymienić takich filozofów jak: Platon, Arystoteles czy Diogenes Laertios.

18 Diogenes Laertios, Żywoty i poglądy stynnych filozofów, tłum. I. Krońska, Warszawa 1984, s. 23.

19 J. Malita-Król, Cztery korzenie rzeczywistości. Analiza porównawcza postrzegania żywiołów u filozofów presokratejskich $i$ we współczesnych tradycjach czarostwa, „Maska. Magazyn antropologiczno-społeczno-kulturowy", nr 33, 2017, s. 158. 
siły zewnętrznej, gdyż sama jest źródłem własnej siły ${ }^{20}$. Jest przyczyną ruchu, życiem i duszą wszelkich istnień. Przenika i buduje świat doczesny, jest nadającą mu byt podstawą ${ }^{21}$. Jako pierwotny budulec rzeczywistości ma w sobie znamiona wieczności, ponieważ nie ma początku ani końca. Na podstawie własnych obserwacji rzeczywistości, w której egzystował, Tales ustalił, że to właśnie woda jest zasadą świata. W kontekście arché świata odnajdujemy wypowiedź Talesa w filozoficznym dziele Arystotelesa zatytułowanym Metafizyka, która brzmi następująco: ,pokarm, jakim żywią się wszystkie jestestwa, jest wilgotny i że z wilgotności powstaje samo ciepło i dzięki temu żyje (a zasadą każdej powstającej rzeczy jest to, $z$ czego ona powstaje). [...] a wszelkie nasienie jest z natury wilgotne, a woda jest zasadą natury rzeczy wilgotnych" ${ }^{22}$. Zatem zgodnie z myślą filozofa, wszystko, co istnieje, pochodzi z wody i z wody się składa. Szukając zasady świata, Tales bada różne zjawiska przyrody ożywionej i nieożywionej. Wprowadza nową metodę badania rzeczywistości - obserwację. Na jej podstawie wyciąga wnioski, budując przy tym nowy obraz rzeczywistości, bez odwoływania się do mitologii. Taki sposób badania rzeczywistości zainicjował myślenie filozoficzne. Teoria owego obrazu świata ma także charakter metafizyczny. Do czasów obecnych przetrwała jedyna wypowiedź Talesa, którą odnajdujemy w dziele Platona Prawa, a która jest w swym sensie zasadniczo religijna. Tales $\mathrm{w}$ trakcie swoich rozważań nad strukturą oraz prawami rządzącymi rzeczywistością przyrodniczą jednoznacznie stwierdzil, że „wszystko jest pełne bogów"23. Grecki myśliciel uważał, że poprzez wodę przejawia się dusza $^{24}$ świata i boska nieograniczona siła, wilgoć była bowiem rozumiana jako boska zasada życia ${ }^{25}$. Stwierdzenie, że wszystko jest pełne bogów, może oznaczać, że cała przyroda zarówno ożywiona, jak i nieożywiona, w całej swej jedności, jest wypełniona tajemniczą mocą. Świat, który nas otacza, jest pełen bogów oraz skutków ich mocy. Zatem bogów można doświadczać przez skutek, jest on bowiem tym, co można zmysłami objąć, to znaczy, wzrokiem ogarnąć i chwytać rękoma ${ }^{26}$. W tymże świecie bogowie nie żyją w odosobnieniu czy w jakimś niedostępnym miejscu dla ludzkich oczu, lecz są przed nami bezpośrednio, są tak naprawdę wszędzie, wystarczy po nich sięgnąć.

${ }^{20}$ J. Bartoszewski, Filozofia przyrody, Kartezjusz i porządek życia społecznego, Lublin 2010, s. 13.

${ }^{21}$ M. Jastrzębski, Wczesna filozofia..., s. 160.

${ }_{22}$ Arystoteles, Metafizyka, t. 1, tłum. T. Żeleźnik, Lublin 1996, s. 20.

${ }^{23}$ Platon, Prawa, thum. M. Maykowska, Warszawa 1960, 899 b.

${ }^{24}$ Według Talesa wszystkie części, które tworzą całość rzeczywistości, mają duszę, która jest zasadą ruchu. Arystoteles w traktacie $O$ duszy cytuje wypowiedź Talesa, który mówi wprost: „wszystko ma duszę”. Zob. Arystoteles, O duszy, thum. P. Siwek, Warszawa 1998, I 2, 405 a19.

${ }_{25}$ W. Tyburski, A. Wachowiak, R. Wiśniewski, Historia filozofii i etyki do wspótczesności. Źródła i komentarze, Toruń 2002, s. 24.

${ }^{26}$ W. Jaeger, Teologia wczesnych filozofów greckich, tłum. J. Wocial, Kraków 2007, s. 55. 


\section{2) Anaksymander $\mathrm{z}$ Miletu}

Filozofię Anaksymandra z Miletu możemy poznać dzięki świadectwu innych myślicieli27, ale także dzięki fragmentowi jego własnego dzieła, który przetrwał do czasów obecnych. Fragment ten składa się tylko z jednego zdania, które jest niezwykle cenne dla poznania i zrozumienia myśli tegoż wybitnego filozofa starożytnej Grecji.

Anaksymander w swoich rozważaniach nad źródłem wszystkich rzeczy jako pierwszy posłużył się terminem arché. Zbudował nowy obraz świata-kosmosu, inaczej niż Tales, który kierował się kategoriami prostej intuicji zmysłowej, na podstawach czysto logicznych: opierając się tylko i wyłącznie na naturalnej dedukcji. Wyjaśniając różne zjawiska rzeczywistości, sięgnął po metodę badawczą charakteryzującą się myśleniem konstruktywnym. Aby poznać źródło wszystkich rzeczy pozostałych, sukcesywnie i gorliwie dążył do odkrycia matematycznego stosunku w proporcji między całością świata a jego poszczególnymi elementami. Dążenie to miało wyjaśnić, że konstrukcja świata opiera się na podstawach geometrycznej schematyzacji, wobec tego świat ze wszystkimi jego częściami należy traktować jako całość. Na podstawie czysto logicznych wniosków Anaksymander odrzucił arché (wodę) swojego mistrza Talesa jako zasadę świata, uzasadniając, że niemożliwe jest, aby mająca jednostronny skład woda mogła być podstawą istnienia innych rzeczy o budowie odmiennej, jak ogień czy ziemia ${ }^{28}$. Także żaden związek, który jest obecny w świecie, nie może być podstawą i tworzywem dla rzeczy pozostałych, gdyż one powstają, zmieniają się i giną, nie mogą przez to uchodzić za pierwotne ${ }^{29}$. Pierwotnym tworzywem musi być coś, co jest nieokreślone czaso-przestrzennie, ilościowo i jakościowo, coś bez własności widzialnych dla ludzkich oczu. Według Anaksymandra, cechą wyróżniającą ową siłę, w której wszystkie inne rzeczy odnajdują swój początek, musi być to, że ona sama w swej naturze jest bezkresna ${ }^{30}$, czyli wolna od wszelkich granic. Simplikios w kontekście pierwszej zasady świata cytuje filozofa z Miletu w ten sposób: „Anaksymander twierdził, że początkiem rzeczy istniejących jest pewna natura bezkresu, z której powstają nieba i zawarte w nich światy" 31 . Tym pierwszym tworzywem, budulcem Wszechświata, z którego czerpie pokarm wszelkie powstające istnienie, co wszystko obejmuje i wszystkim kieruje, według Anaksymandra

\footnotetext{
${ }^{27}$ Należy tutaj wymienić takich filozofów jak: Arystoteles, Simplikios z Cylicji czy Teofrast z Eresos.

28 Tamże, s. 57.

29 J. Bartoszewski, Filozofia przyrody ..., s. 13.

${ }^{30}$ W. Jaeger, Teologia wczesnych ..., s. 57.

31 Simplikios, In Phys., 24, 13, w: Historia filozofii..., s. 25.
} 
jest bezkres - apeiron $^{32}$. Filozoficzna koncepcja apeiron w starożytnej myśli greckiej proponowała ciekawe rozwiązanie w kreowaniu ogólnego obrazu świata. Podaje ona, że $\mathrm{w}$ procesie formowania się świata $\mathrm{z}$ apeiron etapami i stopniowo wyłaniały się przeciwieństwa takie jak: ciepło i zimno, dzień i noc, suchość i wilgoć, a następnie żywioły: woda i ogień, ziemia i powietrze. Owe przeciwieństwa wyodrębniały się wskutek wiecznego ruchu ${ }^{33}$, bez którego nie ma powstawania i zanikania. Czas rodzenia się Wszechświata to także proces cyklicznego niszczenia i odradzania się światów, w konsekwencji dochodzi do niesprawiedliwości, gdyż poszczególne przeciwieństwa zawłaszczają się, niejako wyrządzając tym sobie krzywdę. Obecny porządek Wszechświata nie jest wieczny, kiedyś ponownie przeobrazi się $\mathrm{w}$ apeiron, $\mathrm{z}$ którego się wyłonił. Jedyny ocalały fragment dzieła Anaksymandra, zgodnie z przekazem Simplikiosa, podaje, jak czytamy: „A z czego powstają istniejące rzeczy, $\mathrm{w}$ to niszczeją, zgodnie $\mathrm{z}$ koniecznością: płacą bowiem sobie nawzajem karę i pokutę za niesprawiedliwość, zgodnie z postanowieniem Czasu" ${ }^{34}$.

Należy zauważyć, że powstałe elementy, które sobie nawzajem „oddają” sprawiedliwość, podlegają karze zniszczenia tożsamego $\mathrm{z}$ powrotem do apeiron, realizując tym samym koniecznośc ${ }^{35}$ przemian $\mathrm{w}$ obrębie kosmosu. Apeiron odwiecznie generuje i degraduje elementy kosmosu $\mathrm{w}$ toku ciągłych zmian. Niewątpliwie można przyjąć, że jest to „zależne od posiadania nadmiaru, za który rzeczy muszą płacić odszkodowanie przez odstępowanie innym tego, z czego korzystają obecnie" ${ }^{36}$. Wyodrębnianie, oddzielanie $\mathrm{i}$ formowanie się pierwszych rzeczy z apeiron, ,dokonuje się przeto przed trybunałem czasu, który - jak sędzia w sporze między sąsiadami - czuwa, aby wina została ukarana"37. Czas ujawnia działanie konieczności, czyli samej pierwotnej zasady rzeczywistości, i jednocześnie, w obrębie kosmosu, wyznacza moment rozpadu poszczególnych części oraz ich powrotu do apeiron, czyli określa, kiedy wydany wyrok zostanie spełniony ${ }^{38}$.

W zakres koncepcji apeiron wchodzi element nieskończoności, która ma zdecydowanie metafizyczno-religijny charakter. Owa nieskończoność wplata się w wizję absolutnego początku, gdyż ona sama nie ma początku w czasie, ponieważ nie ma granic. Arystoteles w Fizyce ustala cechy apeiron z pojęcia absolutnego początku tymi słowami:

32 J. Bartoszewski, Filozofia przyrody..., s. 13.

33 Wieczny ruch Anaksymandra ma charakter witalny.

${ }^{34}$ Simplikios, In Phys., 24, 17, „Studia Redemptorystowskie”, nr 11, 2013, s. 27.

35 D.W. Biedrzyński, «Niezrodzony» $i$ «niezniszczalny» jako znaki prawdy w ujęciu Parmenidesa w kontekście pojęcia czasu, „Folia Philosophica”, nr 39, 2018, s. 187.

36 W. Jaeger, Teologia wczesnych..., s. 78.

${ }^{37}$ D. Dembińska, Moja krótka..., s. 28.

${ }^{38}$ D.W. Biedrzyński, «Niezrodzony» $i$ «niezniszczalny»..., s. 188. 
Co więcej, będąc zasadą jest zarazem niestworzona i niezniszczalna. Wszak to, co powstaje, musi mieć swój koniec, a to, co ginie - swój kres. Twierdzimy wobec tego, że nieskończoność nie ma swej zasady, lecz że ona sama uchodzi za zasadę innych rzeczy, że obejmuje wszystko i wszystkim rządzi [...]. Większość filozofów przyrody zgadza się z Anaksymandrem, gdy twierdzi, że nieskończoność jest boska, bo jest nieśmiertelna i niezniszczalna ${ }^{39}$.

Zatem zgodnie z przekazem Arystotelesa nieskończoność, która jest częścią składową koncepcji apeiron, zawiera w sobie cechy boskie, gdyż jest nieśmiertelna i niezniszczalna, zatem wieczna w swej naturze. Nieskończoność nie ma zasady w sensie początku, znaczy to, że jest niezrodzona i nosi w sobie znamiona wieczności, która przysługuje tylko bóstwom. Pośrednio przekazany przez Arystotelesa cytat wypowiedzi filozofa z Miletu na temat pierwotnej zasady świata brzmi następująco: ,, apeiron jest tym, z czego wszystko się wywodzi i do czego wszystko powraca" ${ }^{40}$. Zgodnie z ową myślą, apeiron nie ma początku ani końca, tylko sam jest początkiem i końcem wszystkich rze$\mathrm{czy}^{41} \mathrm{w}$ swoim wiecznym trwaniu. Dla uzupełnienia należy posłużyć się słowami Anaksymandra, które zostały przekazane pośrednio przez Teofrasta z Eresos. Według filozofa pierwotna zasada świata: „Jest [...] wieczna i nie starzeje się, otacza też wszystkie światy"42. Dla uzasadnienia teologicznego znaczenia owej nieskończoności należy ponownie posłużyć się słowami Arystotelesa, jak czytamy:

nieskończoność [...] obejmuje wszystko i wszystkim rządzi, jak twierdzą ci, co nie uznają obok nieskończoności żadnych innych przyczyn, jak np. „Ducha” [Anaksagoras] czy „Miłości” [Empedokles]. Większość filozofów przyrody zgadza się z Anaksymandrem, gdy twierdzi, że nieskończoność jest boska, bo jest nieśmiertelna i niezniszczalna ${ }^{43}$.

Badając element teologiczny w zagadnieniu nieskończoności, warto zwrócić uwagę na określenia, jakich używa Arystoteles. Pojęcie nieskończoności zawiera w sobie takie właściwości jak obejmowanie i rządzenie, znaczy to, że musi być czymś, „,co przez wszystkie rzeczy jest objęte" ${ }^{44}$, czyli otacza wszystko i wszystkim kieruje. Z pewnością musi być czymś wszechobejmu$203 b 6$.

${ }^{39}$ Arystoteles, Fizyka, tłum. K. Leśniak, w: tegoż, Dzieła wszystkie, t. 2, Warszawa 1990, III 4 ,

${ }^{40}$ W. Jaeger, Teologia wczesnych..., s. 65.

${ }^{41}$ Można to także zinterpretować, że apeiron to coś, na zewnątrz czego nic nie istnieje, co nie ma już nic na zewnątrz. Zob. tamże, s. 68.

${ }^{42}$ G.S. Kirk, J.E. Raven, M. Schofield, Filozofia przedsokratejska..., s. 116.

${ }^{43}$ Arystoteles, Fizyka..., III 4, 203 b6.

${ }^{44}$ W. Jaeger, Teologia wczesnych..., s. 66. 
jącym i wszechwładnym, posiadaczem najwyższej mocy i panowania. Musi być czymś aktywnym, dynamicznym, w jakimś sensie motorem dla innych rzeczy, można nawet powiedzieć, że jest najaktywniejszą rzeczą w świecie. Właściwości, takie jak obejmowanie i rządzenie, świadczą o istnieniu cech najwyższych i absolutnych pierwotnej zasady wszystkich rzeczy pozostałych. Zatem pierwotna i najwyższa zasada świata musi być bóstwem. Majestatyczność koncepcji apeiron polega na tym, że zawiera ona w sobie problem transcendentalny, który został odkryty w momencie, gdy Anaksymander dokonał przeniesienia „Boga” czy „bóstwa” z bóstw tradycyjnych na pierwszą zasadę bytu za pomocą samodzielnych racjonalnych dociekań myślowych. Koncepcja apeiron zawiera $\mathrm{w}$ sobie element boskości, którą można rozpoznać po takich atrybutach, jak: nieśmiertelność, nieskończoność czy wieczność. Apeiron jest urzeczywistnieniem bóstwa jako takiego, bez początku i bez końca, zatem wiecznego w swym trwaniu.

Zgodnie z myślą Anaksymandra, wszystko, co dzieje się w świecie, działa według racjonalnych praw, którym człowiek powinien się podporządkować. Prawa te, rządzące całą przyrodą, są wyrazem boskiej sprawiedliwości. Zatem boskość praw objawia się w życiu pojedynczego człowieka, ale również w życiu zbiorowym (społecznym - więziach ludzkich), ekonomicznym (handlu) i politycznym (strukturach państwa).

\section{3) Anaksymenes z Miletu}

Anaksymenes z Miletu, budując własne koncepcje filozoficzne, przejmuje wiele od swoich greckich mistrzów, związanych ze szkołą milezyjską, tj. od Talesa i Anaksymandra. Do czasów obecnych zachowały się jedynie trzy fragmenty z dzieła filozofa. Spuściznę po Anaksymenesie możemy również poznać dzięki przekazom i komentarzom jego uczniów czy kontynuatorów jego myśli ${ }^{45}$.

Anaksymenes w trakcie swoich filozoficznych rozważań nad pierwszą przyczyną wszystkich rzeczy przejmuje arché (bezkres), od swojego nauczyciela Anaksymandra, niejako modyfikując tę koncepcję. Według tegoż greckiego myśliciela niczym nieograniczony bezkres - apeiron, należy uzupełnić ograniczającym powietrzem - aer, które jest składnikiem najbardziej zmiennym i ulegającym transformacjom. Ze względu na swoją strukturę jest składnikiem mającym łatwość przybierania różnych stanów skupienia, co wpływa na podniesienie wartości tego pierwiastka rzeczywistości, nadaje się zatem na pierwotny budulec świata-kosmosu. Według Anaksymenesa powietrze jako pierwotna

${ }^{45}$ Należy tutaj wymienić takich filozofów jak: Teofrast z Eresos, Simplikios z Cylicji czy Aëtios. 
zasada świata objawia się w różnych stanach fizykalnych, przez rozrzedzenie czy zagęszczenie, zgodnie z przekazem Teofrasta z Eresos: „Kiedy jest rozrzedzone, staje się ogniem, kiedy natomiast ulega zgęszczeniu, staje się wiatrem, następnie chmurą, a gdy jeszcze bardziej zgęstnieje, staje się wodą, potem ziemią, wreszcie kamieniem, a z tych właśnie rzeczy powstaje wszystko inne" ${ }^{46}$.

Filozof, poszukując arché świata, poznawał naturę rzeczywistości na podstawie własnych obserwacji. Przyglądając się różnym zjawiskom przyrodniczym, doszedł do wniosku, że kamień jest ciałem najzimniejszym i najbardziej zwartym w swej budowie, natomiast ogień jest substancją najgorętszą i najrzadszą ${ }^{47}$. Podejmował liczne próby wyjaśniania zjawisk takich jak: powstawanie gradu, śniegu czy tęczy. Obserwując niebo, stwierdził, że ciała niebieskie są płaskie i wiszą niczym liście w powietrzu.

Filozoficzna koncepcja arché greckiego myśliciela z Miletu podaje, że początkiem i budulcem wszystkich rzeczy pozostałych jest powietrze, ,z niego bowiem wszystko powstaje i na nie się znowu rozpada"48. Za proces rozrzedzania i zagęszczania, odpowiada ruch powietrza. Według koncepcji, ruch $^{49}$ oznaczał życie, a gdzie jest ono obecne, tam jest aktywna i działająca dusza, odpowiadająca za trwanie świata. Cytując filozofa z Miletu, zgodnie z przekazem Aëtiosa: „Podobnie jak dusza [...], która jest powietrzem, trzyma nas w skupieniu, tak i cały świat również otacza tchnienie i powietrze" ${ }^{50}$. Anaksymenes wprowadza terminologiczne rozróżnienie między powietrzem - aer, a tchnieniem życia - pneuma, jednakże nie różnicuje tych pojęć, tylko traktuje je na równi. Powietrze i tchnienie uważał za synonimy. Zatem powietrze jest tchnieniem, które wypełnia, przenika i pobudza do życia cały kosmos wraz z człowiekiem. Jest jak pokarm dla pozostałych rzeczy, podtrzymuje bowiem funkcje życiowe wszystkich organizmów w świecie przyrody. Wszystko, co żyje, oddycha powietrzem, zaś jego brak oznacza pewną śmierć. Panuje nad całym kosmosem, tak jak dusza panuje nad naszym całym ciałem. Kosmos wraz z człowiekiem składa się z tego samego tworzywa i jest stale i niezmiennie

${ }^{46}$ Simplikios, Komentarz do Fizyki Arystotelesa, 24, 26, tłum. B. Kupis, w: Antologia tekstów filozoficznych, red. K. Kałuża, A. Pelc, Kraków 2002, s. 13. Dla uzupełnienia pragnę dodać, że jest to jeden $\mathrm{z}$ trzech zachowanych fragmentów z dzieła filozofa.

${ }^{47}$ W. Tatarkiewicz, Historia filozofii..., s. 29.

48 W. Tyburski, A. Wachowiak, R. Wiśniewski, Historia filozofii..., s. 25.

49 Łatwo zauważyć, że Milezyjczyk pod inspiracją myśli swojego nauczyciela, przejmuje teorię o wiecznym ruchu. Anaksymenes uważa, że powietrze znajduje się niemal wciąż w stanie ruchu, a kiedy znajduje się w stanie spoczynku, „wtedy nie jest widzialne dla oka, lecz ujawnia się pod postacią zimna, ciepła, wilgoci i ruchu". Zob. Hipolit, Ref., I, 7, 2 = Diels-Kranz, 13 A 7, thum. B. Kupis, Warszawa 1989, s. 12. Dla uzupełnienia pragnę dodać, że jest to drugi z trzech zachowanych fragmentów $\mathrm{z}$ dzieła filozofa.

${ }^{50}$ G.S. Kirk, J.E. Raven, M. Schofield, Filozofia przedsokratejska ..., s. 160. Zacytowane zdanie jest trzecim zachowanym fragmentem $z$ dzieła filozofa. 
poddawany zmiennym procesom i prawom przyrody. Anaksymenes w swoich rozważaniach nad pierwszą przyczyną świata zwraca uwagę, inaczej niż jego greccy poprzednicy, na problem wspólnego pochodzenia świata i człowieka. Człowiek i świat mają wspólne źródło swego pochodzenia. Owa koncepcja zawiera w sobie analogię: identyczne pochodzenia świata (makrokosmosu) i człowieka (mikrokosmosu) ${ }^{51}$ w procesie rodzenia się pierwszych rzeczy. Można by powiedzieć, że człowiek i świat wywodzą się ze wspólnego pnia, którego bytową podstawą jest powietrze. Wątek zawarty w owej koncepcji o wspólnym pochodzeniu świata i człowieka będzie poruszany i rozwijany przez kolejnych filozoficznych myślicieli.

Koncepcja Anaksymenesa zawiera w sobie także element boskości. Należy zwrócić uwagę na zdanie przytoczone przez greckiego filozofa, które mówi, że arché - powietrze jest tym, z czego wszystko się wywodzi, ,z niego bowiem wszystko powstaje" ${ }^{2}$. Skoro powietrze jest źródłem i tworzywem wszystkiego, jest także i dla bogów. Augustyn z Tagasty w swoim dziele Państwo Boże zauważa element boskości w koncepcji presokratyka, mówiąc tymi słowami: Anaksymenes ,istnieniu bogów nie przeczył i nie przemilczał o nich; wierzył jednak, że nie przez nich powietrze owo stworzone jest, lecz że i oni z powietrza powstali" ${ }^{53}$. Bogowie wyłaniają się z powietrza jako swego pierwotnego tworzywa. Anaksymenes, tak samo jak jego nauczyciel Anaksymander, zachował niezliczonych bogów, oznacza to, że częścią składową arché jest także element boskości jako warunek niezbędny do panowania nad wszystkim. Wszystkie rzeczy składają się z podobnych do siebie cząsteczek, a każda z osobna rzecz staje się z właściwych sobie cząstek spośród owych wszystkich cząstek. Wytwórcą rzeczy, które widzimy zewsząd, musi być ktoś o szczególnej mocy i sile. Zatem powietrze jako pierwotna zasada świata, od którego wszystko się zaczęło, musi w swej naturze zawierać rozum boski, bez którego nic by się stać nie mogło. Filozof w trakcie swych rozważań nad pierwszą przyczyną rzeczy pozostałych, mówi: światem rządzą bogowie, którzy wyłonili się z powietrza ${ }^{54}$. Owo zdanie sugeruje nam obecność boskich przyczyn, które ujawniają swoją moc w kreowaniu i rozumnym planowaniu świata.

$*$

Arché przeżywana $\mathrm{w}$ doświadczeniu metafizycznym nie ma $\mathrm{w}$ sobie żadnej „stałej” trwałości, jaką mają elementy świata ujawniającego się

${ }^{51}$ D. Kubok, «Apeiron» Anaksymandra, czyli o tym, co pierwsze w filozofii, „Folia Fhilosophica”, nr 17, 1999, s. 25.

52 W. Tyburski, A. Wachowiak, R. Wiśniewski, Historia filozofii..., s. 25.

${ }^{53}$ Augustyn, Państwo Boże, thum. T. Kubicki, Kęty 2015, s. 290.

${ }^{54}$ W. Jaeger, Teologia wczesnych..., s. 81. 
w poznaniu ukształtowanym przez myślenie dyskursywne. Istnieje zatem pokusa, by określić ją (arché) jako czyste przemijanie, przepływ nieuchwytnej teraźniejszości ${ }^{55}$.

\begin{abstract}
The purpose of this article is an attempt to present one fundamental problem: identification of the essential features of the arché in Milesian philosophers of nature by indicating possible relationships with theology. The theological interpretation of the Milesians indicates that arché does not merely have a material dimension, it is inherently external, going beyond, and consequently, the original principle contains a peculiar transcendence. In the concepts of natural philosophers, there is an archaic path to immortality, infinity, and eternal existence, which are, in essence, divine attributes. There is a clear search to determine the relationship of divine sphere of existence with the world that we know from everyday experience. This means that the Milesians have found a plane on which the divine sphere and the temporal sphere can meet. There are certain frameworks within which there is an interaction between the divine element (constant and invariant) and temporal (transient and finite).
\end{abstract}

Keywords: pre-Socratic philosophy, arché, theology.

Slowa kluczowe: filozofia presokratejska, arche, teologia.

\title{
BIBLIOGRAFIA
}

Arystoteles, Fizyka, III 4, 203b6, tłum. K. Leśniak, w: Arystoteles, Dzieła wszystkie, t. 2, Warszawa 1990.

Arystoteles, Metafizyka, t. 1, thum. T. Żeleźnik, Lublin 1996.

Arystoteles, O duszy, I 2, 405a19, thum. P. Siwek, Warszawa 1998.

Augustyn, Państwo Boże, tłum. T. Kubicki, Kęty 2015.

Aureliusz M., Rozmyślania, II 17, tłum. M. Reiter, Warszawa 1988.

Bartoszewski J., Filozofia przyrody, Kartezjusz i porzadek życia spolecznego, Lublin 2010.

Biedrzyński D.W., «Niezrodzony» $i$ «niezniszczalny» jako znaki prawdy w ujęciu Parmenidesa w kontekście pojęcia czasu, „Folia Philosophica”, nr 39, 2018, s. 179-194.

Copleston F., Historia filozofii, t. 1, tłum. H. Bednarek, Lublin 2004.

Dembińska D., Moja krótka historia filozofii starożytnej, „Studia Redemptorystowskie”, nr 11, 2013, s. 27-52.

Diogenes Laertios, Żywoty i poglądy stynnych filozofów, tłum. I. Krońska, Warszawa 1984.

Ekologia i spoleczeństwo. Polityka i etyka wobec zagadnień ekologicznych, red. A. Delorme, Wroclaw 2001.

Hajduk A., Trzy aspekty ekologii Seneki i św. Franciszka, w: Ekologia i społeczeństwo. Polityka i etyka wobec zagadnień ekologicznych, red. A. Delorme, Wrocław 2001, s. 53-69.

${ }^{55}$ P. Sikora, Metafizyczne doświadczenie niestałej arche, „Analiza i Egzystencja”, nr 41, 2018, s. 40. 
Hipolit, Ref., I, 7, 2 = Diels-Kranz, 13 A 7, thum. B. Kupis, Warszawa 1989, s. 12. Jaeger W., Teologia wczesnych filozofów greckich, thum. J. Wocial, Kraków 2007.

Jastrzębski M., Wczesna filozofia Grecka jako archaiczna droga do nieśmiertelności. Próba rekonstrukcji, Białystok 2014.

Kirk S., Raven J.E., Schofield M., Filozofia przedsokratejska, thum. J. Lang, Warszawa-Poznań 1999.

Kubok D., "Apeiron» Anaksymandra, czyli o tym, co pierwsze w filozofii, „Folia Fhilosophica”, nr 17, 1999, s. 15-28.

Filozofia przyrody współcześnie, red. M. Kuszyk-Bytniewska, A. Łukasik, Kraków 2010.

Lloyd G.E.R., Nauka grecka od Talesa do Arystotelesa, tłum. J. Lesiński, Warszawa 1998.

Łukasik A., Wprowadzenie, w: Filozofia przyrody współcześnie, red. M. Kuszyk-Bytniewska, A. Łukasik, Kraków 2010, s. 5-26.

Malita-Król J., Cztery korzenie rzeczywistości. Analiza porównawcza postrzegania żywiołów u filozofów presokratejskich $i$ we wspólczesnych tradycjach czarostwa, „Maska. Magazyn antropologiczno-społeczno-kulturowy", nr 33, 2017, s. 157-166.

Milczarek-Gnaczyńska M., Jednostka a społeczeństwo. Władysław Mieczysław Kozłowski o człowieku - wybrane aspekty, „Colloquium Wydziału Nauk Humanistycznych i Społecznych”, nr 4, 2013, s. 7-16.

Palacz R., Klasycy filozofii, Warszawa 1987.

Platon, Prawa, 899 b, tłum. M. Maykowska, Warszawa 1960.

Reale G., Historia filozofii starożytnej, t. 1, tłum. E.I. Zieliński, Lublin 2000.

Simplikios, In Phys., 24, 13, w: W. Tyburski, A. Wachowiak, R. Wiśniewski, Historia filozofii i etyki do wspótczesności. Źródta i komentarze, Torun 2002, s. 25-30.

Simplikios, In Phys., 24, 17, „Studia Redemptorystowskie”, nr 11, 2013, s. 27-52.

Simplikios, Komentarz do Fizyki Arystotelesa, 24, 26, thum. B. Kupis, w: Antologia tekstów filozoficznych, red. K. Kałuża, A. Pelc, Kraków 2002, s. 13-20.

Subczak M., Antyczna tradycja filozoficznych sposobów życia jako wzorzec dla współczesności, „Logos i Ethos”, nr 1 (44), 2017, s. 7-31.

Tatarkiewicz W., Historia filozofii, t. 1, Warszawa 1978.

Tyburski W., Wachowiak A., Wiśniewski R., Historia filozofii i etyki do współczesności. Źródta i komentarze, Toruń 2002. 